\title{
The Effect of Flipped Learning on Academic Performance as an Innovative Method for Overcoming Ebbinghaus' Forgetting Curve
}

\author{
Bo Ae Chun \\ Catholic Kwandong University \\ 24 Beomil-ro 579beon-gil \\ Gangneung-si, Gangwon-do, South Korea \\ +82-33-649-7753 \\ boaechun@cku.ac.kr
}

\author{
Hae Ja Heo* \\ Catholic Kwandong University \\ 24 Beomil-ro 579beon-gil \\ Gangneung-si, Gangwon-do, South Korea \\ +82-33-649-7775 \\ hjheo@cku.ac.kr
}

\begin{abstract}
Recently, flipped learning has been attracting as an alternative teaching and learning method for university education. The purpose of this study is to propose flipped learning as an effective review method overcoming forgetting curve. This study is also aimed to provide empirical evidence for the effect of flipped learning in terms of both self-efficacy and academic performance. Three research questions guided the study: 1) Is there a difference in self-efficacy between traditional lecture style classroom and flipped classroom? ;2) Is there a difference in academic performance between traditional and flipped classroom? ; 3) If so, what is the main factor of the improvement? In this paper, a model of flipped learning supported by LMS is designed to allow students to practice 4 times of review methods while students follow the process of flipped learning of pre-, in- and post- class and reviewing as a self-directed learning.
\end{abstract}

\section{CCS Concepts}

- Applied computing $\rightarrow$ Learning management systems

- Applied computing $\rightarrow$ E-learning

\section{Keywords}

flipped learning; motivation; self-efficacy; Ebbinghaus' forgetting curve; LMS

\section{INTRODUCTION}

According to Ebbinghaus' forgetting curve, there is a strong correlation between memory and time $[1,2]$. Generally, forgetting occurs rapidly at first then slows down. In order to remember newly informed data, it is necessary to practice effective review methods.

Permission to make digital or hard copies of all or part of this work for personal or classroom use is granted without fee provided that copies are not made or distributed for profit or commercial advantage and that copies bear this notice and the full citation on the first page. Copyrights for components of this work owned by others than ACM must be honored. Abstracting with credit is permitted. To copy otherwise, or republish, to post on servers or to redistribute to lists, requires prior specific permission and/or a fee. Request permissions from Permissions@acm.org.

ICIET 2018, January 6--8, 2018, Osaka, Japan

(c) 2018 ACM. ISBN 978-1-4503-5359-5/18/01 ...\$15.00

DOI: https://doi.org/10.1145/3178158.3178206
Experiments have shown that if you memorize repeatedly within one hour, you will remember for one day, if you memorize one day later, you will remember for a week [3]. Figure 1 illustrates the effect of the review. When many forgetfulness occurs, the memory rate increases. The time when forgetfulness occurs is immediately after class, on the evening of the class, the next day, week, month, and so on $[4,5]$. Thus, it is suggested that four or five times review on what you have learned: right after the lesson, the evening, one week later, and one month later. These repeated reviews help learners keep high rate of retention [5].

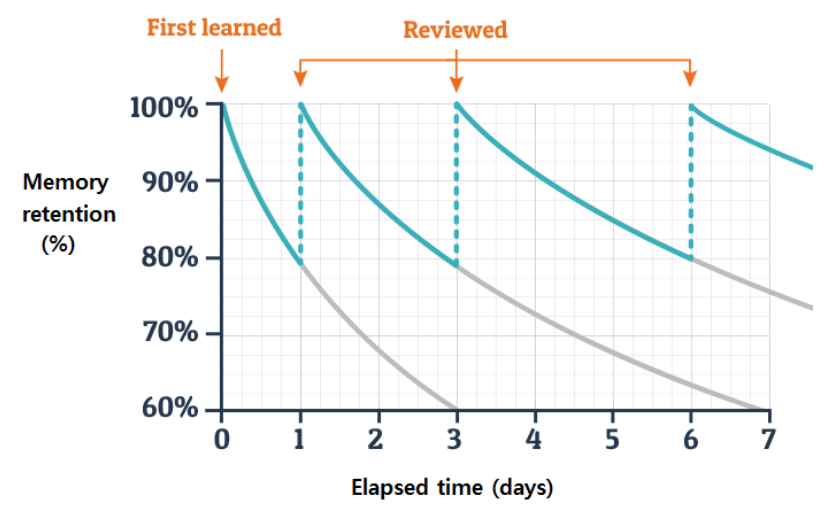

Figure 1. Ebbinghaus' forgetting curve and review cycle.

Recently, flipped learning has been attracting as an alternative teaching and learning method for university education $[6,7]$. The purpose of this study is to propose flipped learning as an effective review method overcoming forgetting curve. This study is also aimed to provide empirical evidence for the effect of flipped learning in terms of both self-efficacy and academic performance. Three research questions guided the study: 1) Is there a difference in self-efficacy between traditional lecture style classroom and flipped classroom? ; 2) Is there a difference in academic performance between traditional and flipped classroom? ; 3) If so, what is the main factor of the improvement?

\section{RELATED WORK}

Flipped learning is a form of blended learning that incorporates technology and classroom instruction [8], which is usually provided with Learning Management Systems (LMS) effectively. Flipped learning is a teaching method that uses technology to implement student-centered class. Literally, flipped learning

\footnotetext{
* Corresponding author
} 
means that things that have traditionally been done in the classroom take place outside the classroom, and that what has happened outside the classroom is done in the classroom [8, 9]. Thus, flipped learning is an evolutionary form of university elearning that induces changes in existing educational systems. Researches show that flipped learning has a significant effect on students' academic achievement, satisfaction, participation, and active learning [10, 11, 12]. A recent study about students' affective pathway reveals that flipped learning cultivates positive local affect such as self-esteem, motivation, and academic interest [13].

In fact, flipped learning as learner-centered teaching methods is not new at all [14]. Since the introduction of constructivism, project-based learning, and problem-based learning, the importance of learner-centered instruction has been emphasized. But the reason why recently flipped learning is getting attention is because it makes it easy to use online videos anytime and anywhere with mobile technology [15]. The Khan Academy is the most representative example of using online video for learning. At the heart of the idea is that instead of providing a lecture to all students in the classroom, the students use the video clips and/or other materials before the class and perform his/her individualized learning according to his/her own pace and needs. In the classroom, teachers can conduct a variety of ways of learning activities such as discussion, project, and practice besides lectures. The most important thing in flipped learning is not the lecture video but the 'face-to-face' interaction and meaningful learning activity. In other words, the center of learning should be the students, not the teachers [16].

Like everything else, flipped learning is not a panacea. There is a lack of research on relationship between the effect of flipped learning and review method overcoming Ebbinghaus' forgetting curve. In order to integrate flipped learning to classroom in a seamless manner, it is necessary to develop instructional strategies that can enhance students' self-directed learning and reinforce effective learning habits [8]. Furthermore, with the advent of smart society, LMS is now prevalent in the learning environment of university [13]. To make the best of LMS, e-learning, and/or blended-learning, we still have a lot to learn about students' learning context and to develop strategies through data analysis on LMS.

\section{RESEARCH METHOD}

\subsection{Participants}

Participants consisted of sophomore students ( $n=37,26$ male, 11 female) at C University in the South Korea who were enrolled in a class of Introduction to Mathematics Education. Students had no prior knowledge of flipped learning.

\subsection{Research Design}

In order to investigate the answer for the research questions, a research protocol has been deliberately designed (see Figure 2).

\begin{tabular}{|l|l|l|l|l|l|l|l|l|l|l|l|l|l|l|l|}
\hline \multicolumn{1}{|c|}{ Week \# } & 1 & 2 & 3 & 4 & 5 & 6 & 7 & 8 & 9 & 10 & 11 & 12 & 13 & 14 & 15 \\
\hline Lecture-style class & & & & & & & & & & & & & & & \\
\hline Flipped learning & & & & & & & & & & & & & & & \\
\hline Mid-term and final exam & & & & & & & & & & & & & & & \\
\hline $\begin{array}{l}\text { Satisfaction questionaries } \\
\text { and survey about } \\
\text { learning style }\end{array}$ & & & & & & & & & & & & & & & $\checkmark$ \\
\hline Self-efficacy test & & & & & & & & $\checkmark$ & & & & & & & $\checkmark$ \\
\hline
\end{tabular}

Figure 2. Research Procedure.
Among the course of class of 15 weeks, the first half of the semester was taught by lecture-style. After mid-term exam, flipped learning was introduced for 6 weeks. Students were guided to watch the movie clip via LMS before class, to participate in the various activities during class, and to keep reflection journal after class. Also, students were encouraged to review the movie clip after class and then, before final exam. Figure 3 shows a screenshot of flipped learning supported by LMS.

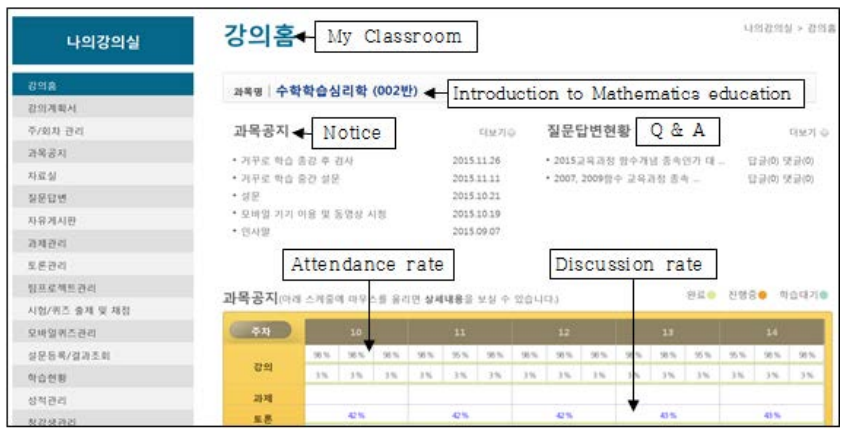

Figure 3. Screenshots of flipped learning supported by LMS.

\section{RESULTS}

\subsection{Academic Performance}

After 6 weeks of intervention of flipped learning, students final exam scores were compared with attendance rate of LMS data accordingly (see Figure 4).

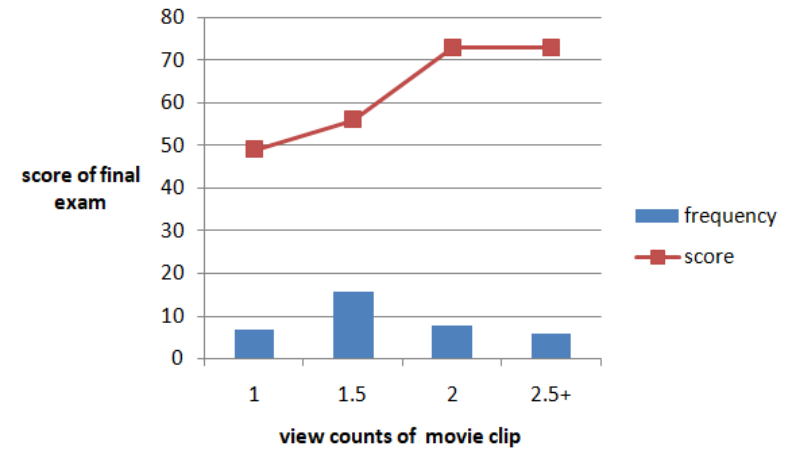

Figure 4. Relationship between academic performance and view counts of movie clip.

In order to investigate the difference between view counts of movie clip, independent samples t-test was performed. There was statistically significant difference between two groups of more than 2 times and less than 2 times.

Table 1. Results of independent samples t-test between groups of view counts of movie clip

\begin{tabular}{lccccc}
\hline & Group & \multicolumn{3}{c}{ Descriptive statistics } & \multirow{2}{*}{$\mathrm{t}(p)$} \\
\cline { 2 - 5 } & & $\mathrm{N}$ & Mean & $\mathrm{SD}$ & \\
\hline $\begin{array}{l}\text { View } \\
\text { counts of } \\
\begin{array}{l}\text { movie } \\
\text { clip }\end{array}\end{array}$ & $\begin{array}{c}\text { Less than } 2 \\
\text { times }\end{array}$ & 23 & 54.22 & 23.36 & $\begin{array}{c}-2.304 \\
\left(0.027^{*}\right)\end{array}$ \\
\cline { 2 - 5 } & $\begin{array}{c}\text { More than } \\
\text { 2 times }\end{array}$ & 14 & 72.71 & 24.23 & \\
\hline
\end{tabular}

$* \mathrm{p} \leq .05$

The results were also confirmed with other evidence. Several quotes from students' journals show the effect of flipped learning and the process of review. 
I was able to open the book every week and study it on my own, so that my understanding of the class was improved during the semester.I also had more concentration than any other class. If I become a secondary school teacher later, I would like to try it.

(Park's reflection journal, week \#12)

I have a habit of doing preparations in advance. Also, the amount of time for studying seems to be increased. I think I have been working with other group members and actively participating in the class.

(Lee's reflection journal, week \#12)

\subsection{Satisfaction Questionnaires}

It is necessary to scrutinize students' satisfaction questionnaires to figure out how students think of flipped learning and among various activities of pre-class, in-class and after-class what kind of activities were helpful. Students were asked to answer "very satisfied"(5) to "very dissatisfied"(1) using 5-point Likert scale format. As shown in Table 2, overall students were satisfied with flipped learning $(\mathrm{M}=3.70, \mathrm{SD}=0.94)$. Mini-lecture followed by Quiz was mostly satisfied and reflection journal during pre-class was least satisfied.

Table 2. Results of satisfaction quesionaires with regard to flipped learning activities

\begin{tabular}{l|lll}
\hline & Survey Items & Mean & SD \\
\hline pre-class & Reflection journal & 3.07 & 0.88 \\
\hline in-class & Quiz & 4.17 & 0.89 \\
& Mini-lecture & 4.24 & 0.64 \\
& Mind-map & 2.93 & 0.78 \\
& Making terminology dictionary & 3.79 & 0.99 \\
& Problem solving & 3.97 & 0.91 \\
& Referring to secondary school & 3.55 & 0.83 \\
& textbooks & & \\
& Solving previous teacher & 4.21 & 0.77 \\
& employment exam & & \\
\hline $\begin{array}{l}\text { after- } \\
\text { class }\end{array}$ & Reflection journal & 3.38 & 0.73 \\
\hline
\end{tabular}

\subsection{Survey with regard to Learning Style}

After 3 and 6 weeks of flipped learning respectively, survey with regard to students learning style was distributed in order to identify any changes in total amount of studying time (see Figure 5). Students' total video watching time has been dramatically increased from 26.9 to $34.48 \mathrm{~min}$. Given that the length of the video per class is around 15 minutes, students do not just watch the video passively, but occasionally stop the video, learn more details in the text, and explore self-directed learning.

Based on the data analysis of LMS, results showed that students usually watch a lecture video the day before the flipped learning class. It also has the same effect as doing the 1st review while doing various in-class activities. After completing the course, students will be given the 2nd review as they write reflection journals. Then, before the test, students watch the video once again and eventually they start to study 4 times. The effect of flipped learning was also confirmed in the t-test of the independent variables between the students' final exams and the students who watched the videos more than once. Figure 6 shows exemplary cases of LMS analytics of a good case and a bad case of self-directed learning.

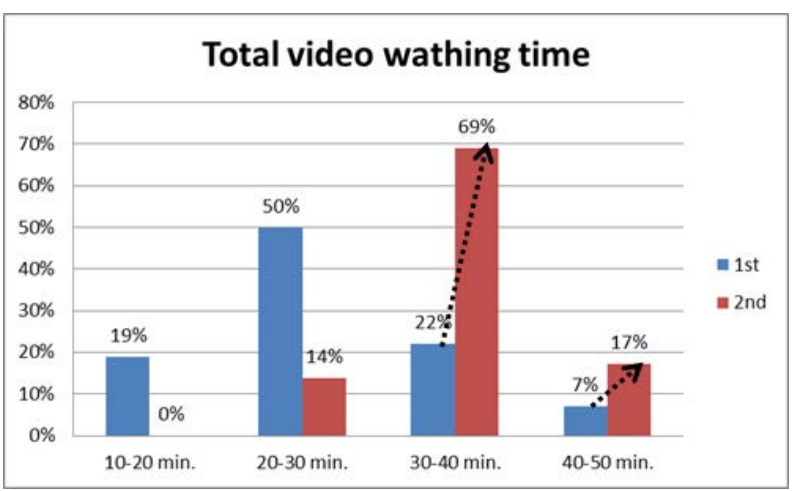

Figure 5. Changes of total amount of studying time.

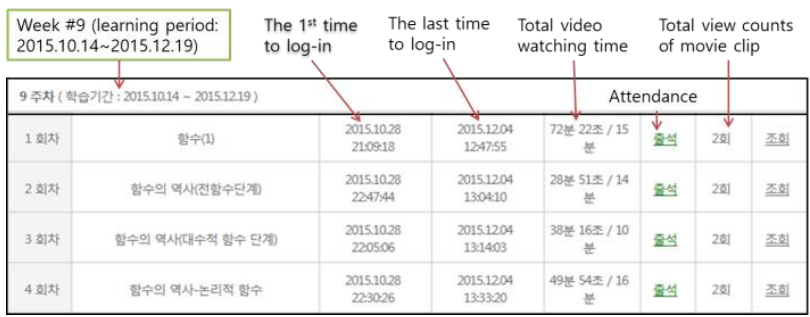

(a) A good case of self-directed learning

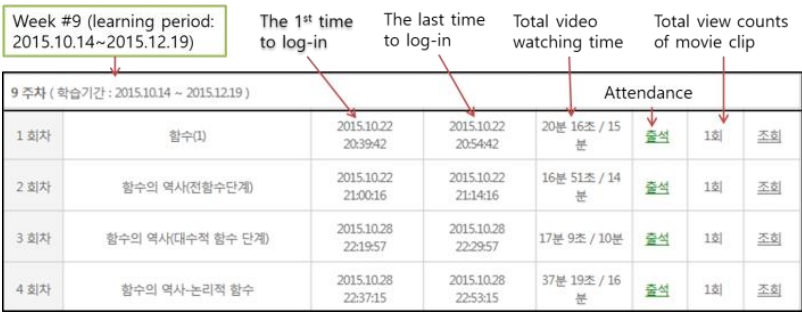

(b) A bad case of self-directed learning

Figure 6. Exemplary cases of LMS data analytics.

In Figure 6 (a), a student logged in to LMS to watch a movie clip more than 2 times, occasionally 4 times and total video watching time is mostly more than 40 min. However, (b) student logged in only 1 time and watched video clips for less than $20 \mathrm{~min}$.

\subsection{Self-Efficacy Test}

Self-efficacy test was held before and after the intervention of flipped learning. Test instrument was adapted from Kim et.al (2014) [8]. The questionnaires consist of 8 items of selfconfidence, 12 items of self-regulation efficacy, and 5 items of task difficulty preference. Students answered with 4-point Likert scale format from "strongly agree"(4) to "strongly disagree"(1).

To examine whether there is a change in students' self-efficacy before and after flipped learning, a paired-sample t-test was conducted. As shown in Table 3, overall self-efficacy was 1.91 points higher in the post-test than in the pre-test, but this result was not statistically significant $(\mathrm{t}=-1.58, \alpha>.01)$. Among the subscales of confidence $(\mathrm{t}=-3.06, \alpha<.01)$ were significantly improved. 
Table 3. Results of self-efficacy and sub-scales of paried sample t-test between pre-and post-test

\begin{tabular}{|c|c|c|c|c|c|c|c|}
\hline & & \multicolumn{3}{|c|}{ Mean Difference } & \multirow{2}{*}{$t$} & \multirow{2}{*}{$d f$} & \multirow{2}{*}{$\begin{array}{c}\text { sig. } \\
\text { (two- } \\
\text { tail) }\end{array}$} \\
\hline & & Mean & SD & SE & & & \\
\hline \multirow{2}{*}{$\begin{array}{c}\text { Self- } \\
\text { efficac } \\
y\end{array}$} & $\begin{array}{l}\text { pre- } \\
\text { test }\end{array}$ & 69.68 & 7.674 & 1.316 & \multirow{2}{*}{-1.582} & \multirow{2}{*}{33} & \multirow{2}{*}{0.123} \\
\hline & $\begin{array}{l}\text { post- } \\
\text { test }\end{array}$ & 71.59 & 8.342 & 1.431 & & & \\
\hline \multirow{2}{*}{$\begin{array}{l}\text { Confid } \\
\text { ence }\end{array}$} & $\begin{array}{l}\text { pre- } \\
\text { test }\end{array}$ & 21.47 & 2.946 & 0.505 & \multirow{2}{*}{-3.058} & \multirow{2}{*}{33} & \multirow{2}{*}{$0.004^{*}$} \\
\hline & $\begin{array}{l}\text { post- } \\
\text { test }\end{array}$ & 23.24 & 3.718 & 0.638 & & & \\
\hline \multirow{2}{*}{$\begin{array}{l}\text { Self- } \\
\text { regulat } \\
\text { ion } \\
\text { efficac } \\
y\end{array}$} & $\begin{array}{l}\text { pre- } \\
\text { test }\end{array}$ & 35.47 & 3.620 & 0.621 & \multirow{2}{*}{0.354} & \multirow{2}{*}{33} & \multirow{2}{*}{0.726} \\
\hline & $\begin{array}{l}\text { post- } \\
\text { test }\end{array}$ & 35.24 & 4.149 & 0.712 & & & \\
\hline \multirow{2}{*}{$\begin{array}{c}\text { Task } \\
\text { difficu } \\
\text { lty } \\
\text { prefere } \\
\text { nce }\end{array}$} & $\begin{array}{l}\text { pre- } \\
\text { test }\end{array}$ & 12.74 & 2.453 & 0.421 & \multirow{2}{*}{-1.232} & \multirow{2}{*}{33} & \multirow{2}{*}{0.227} \\
\hline & $\begin{array}{l}\text { post- } \\
\text { test }\end{array}$ & 13.12 & 2.483 & 0.426 & & & \\
\hline
\end{tabular}

$* \mathrm{p} \leq .01$

\section{DISCUSSION AND CONCLUSION}

In cognitive psychology, the study of forgetting and memory has long been considered the most important issue. Forgetting occurs rapidly soon after initial learning and the rate of memory retention (\%) then gradually declines. Thus, researches recommend that four or five times review on what you have first learned: right after the lesson, the evening, one week later, and one month later. Flipped learning has a similar effect of review methods to overcome Ebbinghaus' forgetting curve by pre-class, in-class, and after-class activities. Furthermore, students can increase the length of retention by reviewing movie clip after the class. Figure 7 illustrates the similar effect of flipped learning and effective retention review method.

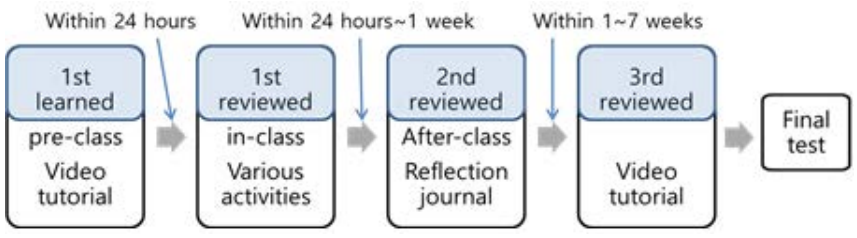

Figure 7. Effect of flipped learning overcoming Ebbinghaus' forgetting curve.

Quoted passages from interviews with students revealed that students were participated in actively, have had the initiative in learning and felt confident of his/her learning.

I was able to get a better understanding of the video while I was previewing it, and it was also fun to solve the problem...I usually sleep during class, but I do not sleep in the flipped learning classroom and concentrate on classes.

(An interview with Lee, week \#15)

In flipped learning, the content of the class was better understood because I came to watch the movie in advance... I think the advantage of flipped learning is that I can watch videos at any time I want and anywhere I go. Also I can study it repeatedly at my own pace.

(An interview with Kweon, week \#15)

Of course, there were also negative responses about flipped learning. Slightly skeptical students about flipped learning tended to think that lecture-style instruction was a more effective learning method. The reason for this was the ease of understanding and concentration on the class. They preferred the instructor's explanation and showed a negative reaction to the students' group activities and presentation due to of the distraction.

Still, there is lack of research with regard to students' learning and the effect of flipped learning. This paper examined the relationship between students' learning style with regard to flipped learning and academic performance empirically. There was a significant difference between two groups of total video watching time with more than 2 times and less than 2 times. Student's satisfaction questionnaires shows students were mostly satisfied with various kinds of in-class activities such as quiz, mini-lecture, mind-map, and problem solving. Survey with regard to learning style also reveal that the total time of watching video are dramatically increased, which means flipped learning has enabled students to have self-directed learning skills. A paired sample t-test was conducted to investigate where there is a change in self-efficacy before and after flipped learning. The results show that confidence among three subscales of self-efficacy was improved significantly. Various kinds of data such as interviews with students and self-reflection journal also support the claims found in the above.

Ebbinghaus' forgetting curve is well known but it is difficult to practice effective review methods. On the other hand, in this paper a model of flipped learning is designed to allow students to practice 4 times of review methods while students follow the process of flipped learning of pre-, in- and post- class and reviewing as a self-directed learning. At the college level, it is boring when an instructor emphasizes only repetition. However, a model of flipped learning that proposed in this study approaches with variety kinds of in-class activities and makes the best of LMS in order to monitor and promote students' learning environment.

In this study, we first applied flipped learning, which has recently been attracting attention as an innovative learning method for 6 weeks and empirically investigated through various evidence such as self-efficacy, academic performance, satisfaction survey, questionnaire and interview, which is different from previous research. In addition, there is a significant point in the attempt to connect the Ebbinghaus' forgetting curve and effective review method with flipped learning model and LMS, which has never been studied.

\section{REFERENCES}

[1] Ebbinghaus, H. 1964. Memory: A contribution to experimental psychology. Oxford, England: Dover

[2] Anderson, J. R. 2000. Learning and Memory (2nd ed.). New York: John Wiley.

[3] Bacon, D.R and Stewart, K.A. 2006. How fast do students forget what they learn in consumer behavior?: A longitudinal study, Journal of Marketing Education, 28(3). 181-192.

[4] Finkenbinder, E. O. 1913. The Curve of Forgetting. The American Journal of Psychology, 24, 1 (Jan, 1913), 8-32. 
DOI=http://www.jstor.org/stable/1413271?seq=1\#page_scan _tab_contents

[5] Sol, Y. W. 2016. Effective Review Methods Based on the Ebbinghaus' Forgetting Curve, Journal of Learning Strategy Intervention, 7, 1, 1-18.

[6] O'Flaherty, J. and Phillips, C. 2015. The use of flipped classrooms in higher education: A scoping review. The Internet and Higher Education, 25, 85-95.

[7] Berrett, D. 2012. How 'flipping' the classroom can improve the traditional lecture. The chronicle of higher education, 12, $1-14$.

[8] Kim, N. I., Chun, B. A., \& Choi, J. I. 2014, A Case Study of Flipped Learning at College: Focused on Effects of Motivation and Self-efficacy. J. of Educational Technology, 30, 3, 467-492.

[9] Bergmann, J. and Sams, A. 2012. Flip your classroom: Reach every student in every class every day. Oregon: ISTE.

[10] Francl, T. J. 2014. Is flipped learning appropriate? Journal of Research in Innovative Teaching, 7(1), 119-128.

[11] Bates, S. and Galloway, R. 2012. The inverted classroom in a large enrolment introductory physics course: A case study. In Proceedings of the Higher Education Academy STEM conference (The London, The UK.)

DIO=http://www.heacademy.ac.uk/assets/documents/stemconference/PhysicalSciences/Simon_Bates_Ross_Galloway. pdf
[12] Enfield, J. 2013. Looking at the impact of the flipped classroom model of instruction on undergraduate multimedia students at CSUN. TechTrends, 5, 6, 14-27.

[13] Heo, H. J. and Chun, B. A. 2016, A Study on the Effects of Mobile-based LMS on Flipped Learning: Focused on the Affective Pathway in Pre-service Teacher Education, International Journal of Software Engineering and its Applications, 10(12), 473-484.

DOI=http://www.sersc.org/journals/IJSEIA/vol10_no12_201 6/39.pdf .

[14] Bergmann, J. and Sams, A. 2013. Flip your students' learning. Educational leadership, 70(6), 16-20.

[15] Davies, R. S., Dean, D. L., \& Ball, N. 2013. Flipped the classroom and instructional technology integration in a college-level information systems spreadsheet course. Educational Technology Research \& Development, 61, 563580.

[16] Raths, D. 2014. Nine video tips for a better flipped classroom. The Education Digest, 79(6), 15-21. https://search.proquest.com/docview/1496698774?accountid $=29319$ 